Ibn Al-Haitham Jour. for Pure \& Appl. Sci. 33 (2) 2020

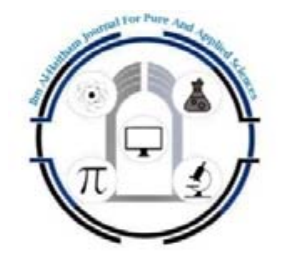

Ibn Al Haitham Journal for Pure and Applied Science

Journal homepage: http://jih.uobaghdad.edu.iq/index.php/j/index

\title{
Nutritional Value of White Button Mushroom (Agaricus bisporus) Which is Most Widely Consumed in Kurdistan Region-Iraq
}

\author{
Hawrez Ali Nadir \\ Horticulture and \\ Landscape Design \\ Department, Technical \\ College of Applied \\ Sciences, Sulaimani \\ hawrez.nadir@spu.edu.iq
}

\author{
Adel Mohan Aday Al-Zubaidy \\ Horticulture and \\ Landscape Design \\ Department, Technical \\ College of Applied \\ Sciences, Sulaimani \\ adel.adday@spu,edu.iq
}

Areej A. Farman Al-Rawi

\author{
Kocher Jamal Ibrahim \\ Food Industry Department, \\ Agriculture College, \\ Sulaimani University, \\ Sulaimny, Kurdistan Region- \\ Iraq. \\ kocher.ibrahim@univsul.edu.iq
}

Department of Biology - College of

Education for Pure

Science, University of

Baghdad- Iraq.

areej_alwrd@yahoo.com

\begin{abstract}
Article history: Received 2 October 2019, Accepted 7 January 2020, Published in April 2020.
\end{abstract}

Doi: 10.30526/33.2.2437

\begin{abstract}
This study was conducted in 2018, at Technical College of Applied Sciences, Sulaimani Polytechnic University, and Kurdistan Region-Iraq. The aim of the study was to determinate nutritional compositions and some elemental contents in marketable white button mushroom (Agaricus bisporus) that is collected in local markets of Kurdistan Region-Iraq. Five different samples (A: Penjwen product fresh, B: Sulaimani product fresh, C: American caned, D: Valencia Netherlandcaned and E: Erbil product fresh) were collected to be observed. The elements were analyzed by Atomic Absorption Spectrometry methods, and their chemical compassions were determined, too. The collected data were analyzed by One Way ANOVA. The highest fat, protein, fiber and dry matter were obtained from treatment B $(3.93 \%, 43.693 \%$, $15.8 \%$ and $10.611 \%$ ) respectively, and the highest carbohydrate and moisture were found from treatment D (49.267\% and 95.053\%). The maximum percentage of ash was taken from E (14.11\%). Moreover, the highest metabolizable energy was taken from treatment D (296.105
\end{abstract}


$\mathrm{kcal} \%$ ) and the lowest was taken from parameter E (223.097 kcal \%). The highest mineral contents (Zn:15, Mn:1.1, Cu:3.5, Ni:1, Ca:6.7 and Mg:90 ppm) from B, (Fe:15 ppm) from C, (Si:350ppm) from A, and (Na:1080 ppm) from D were taken. However, the lowest elemental contents (Fe:6, Mn:0.48, Ni:0.6, Na:180 and Ca:3.5 ppm) from E, (Zn:5, Cu:0.9 and Mg:35 $\mathrm{ppm})$ from D and B (Si:120 ppm) were taken. Therefore, we recommend carrying out more studies on micronutrients for different marketable crops and consuming fresh mushroom instead of caned mushrooms.

Keyword: Agaricus bisporus, white button mushroom, nutrition, element and chemical composition.

\section{Introduction}

Agaricus bisporus, an edible mushroom, belongs to the family of Basidiomycetes, and it is saprophytic, which decomposes agricultural waste and wooden plant [1,2]. Most of the resent studies have regarded approximately (53-110 thousand) of total species of mushroom, but only about 2000 species are recognized, and 60 species are commercially acceptable [3]. A long time ago, mankind has consumed mushroom as food [2, 4]. However, today, human is consuming mushroom for some reasons such as food, health, and human disease $[1,2,5]$.

Although button mushrooms is a common product in the world, its production has rapidly increased day by day [6]. The first leader country for producing button mushroom is China, which supplies $87 \%$ globally; on the other hand, United States (US) is the second largest country after China to supply button mushrooms. In 2016, consumed mushroom is around 450,000 metric tons from the US, a proximately $12 \%$ of mushroom exported and $1 \%$ of that imported $[7,8]$.

The most important species of mushroom commercially grown is Agaricus, especially Agaricus bisporus. Thus, people in the winter and spring collect white button mushrooms from the nature [1]. Also, some farmers cultivate Agaricus bisporus on different types of agricultural waste after composting them [1,2]. In addition, mushrooms play an important role in ecosystem because myceliums of the mushroom are able to biodegrade the agricultural and plant waste [9].

Agaricus bisporus contains many vital substances, such as protein, fat, carbohydrate, ash, moisture and fiber. Furthermore, it is rich with vitamins (B complex, D, K, E and C) [10]. Finally, it contains some elements (Iron (Fe), Magnesium (Mg), Manganese (Mn), Couper $(\mathrm{Cu})$, (Zinc) Zn, (Nickle) Ni, (Silicon) Si, (Sodium) Na, and (Calcium) Ca) [11]. Additionally, nutritional composition, which is directly related to the mushroom, is affected by some factors that are substrate and growing technics [2, 5, 12]. Likewise, mushroom cultivation on agricultural waste is higher than cultivation of agriculture crops such as vegetable and fruit on agricultural waste, so mushroom is very effective to uptake heavy metals from the nature [13].

Agaricus bisporus is a major mushroom cultivation and is used in Kurdistan Region. At that region, some of them can be found in the market. People consume Agaricus bisporus as daily meals. White button mushroom is valuable and low-priced so that it is important in the region. Likewise, in Kurdistan Region-Iraq, three main mushroom production farms can be found in different places, such as Penjwen, Erbil and Sitek. Thus, in Kurdistan Region- Iraq, different types of substrate have been used for mushroom production. It has a good ecological factor to 
grow and cultivate mushrooms [14]. This study will address chemical compositions and some heavy metals of the most popular mushroom that people are mostly consuming in the Region in order to determine nutritional values of the mushroom.

\section{Material and Methods}

This study was conducted in Halabja Technical College of Applied Sciences, Sulaimani Polytechnic University in 2018. Samples of mushroom were obtained from local markets in different territories, such as Erbil, Sulamani, and Halabja. Five marketable mushrooms that are continuously consumed in Kurdistan Region-Iraq were selected to evaluate nutritional values, chemical compositions, and some heavy metals (Fe, $\mathrm{Mg}, \mathrm{Mn}, \mathrm{Cu}, \mathrm{Zn}, \mathrm{Ni}, \mathrm{Si}, \mathrm{Na}$, and $\mathrm{Ca}$ ) Table 1. The collected samples were dried in oven at $65^{\circ} \mathrm{C}$ for 72 hours. Then, each sample was mixed with fine dryer powder. Next, from each treatment, three samples were obtained to evaluate the moisture, protein, ash, fiber, fat, and carbohydrate [15].

Five grams of fresh mushroom samples were weighted to evaluate moisture content in them. Then, the samples were put into oven at $105{ }^{\circ} \mathrm{C}$ for three hours until the weight of samples got constant. The moisture contents were calculated by the following equation (1) [15].

Moisture $\%=\frac{W t_{\text {Sample }}-W t_{\text {Sampe after dried }}}{\text { Weight of sample }} \times 100$

'Soxhlet extracto' method was used to evaluate the fat contents, cited by [16]. 10 $\pm 0.1 \mathrm{gm}$ of mushroom was sampled, and the petroleum Ether was used in a Soxhlet for sixteen hours. After that, the samples were put in oven at $105{ }^{\circ} \mathrm{C}$ for one hour and were calculated by the following equation (2).

$F a t \%=\frac{100\left(\mathrm{Wt}_{1}-\mathrm{Wt}_{2}\right)}{\text { wight of sample }}$

$W t_{1}=$ Weight of Soxhlet flask with extract fat

$W t_{2}=$ Weight of empty Soxhlet flask

Kjeldahl method' was used to determine protein contents in this study. $0.7 \pm 0.05$ gm of dry mushroom was weighted, and sensitive electronic balance was used to analyze. Then, the samples were put in digestion flask until they became colorless with adding $1 \mathrm{gm}$ of copper sulphate, 10 gm Potassium Sulphate, and $20 \mathrm{ml}$ Sulfuric acid. After that, the digestion contents were transferred to the vessel. Then, $25 \mathrm{ml}$ of Sulpharic acid $0.2 \mathrm{~N}$ was pipetted out into beaker. Distillation was started in Kljdahl device, and the distillated sample was allowed to collect in Sulpharic acid for a known volume and time. Next, the collected distillation-(was) titrated against $0.2 \mathrm{~N}$ Sodium Hydroxide using Methyl red as an indicator to determine the amount of Nitrogen. The Nitrogen was taken from the sample multiplied by 6.25 factors to get the percentage of real total protein [17].

The percentage of Nitrogen and protein was calculated by the following equation (3), and (4).

$N \%=\frac{\text { (Titer Blank }- \text { Titer sample) } * 0.014 * 1000}{\text { wight of sample }}$

Protein $\%=\mathrm{N} \% * 6.25$ 
Ibn Al-Haitham Jour. for Pure \& Appl. Sci. 33 (2) 2020

Table 1. Illustrated the mushroom, Agaricus bisporous, samples that were evaluated in this study.

\begin{tabular}{|c|c|c|c|}
\hline Treatment & $\begin{array}{l}\text { Types product mushroom } \\
\text { from supermarket }\end{array}$ & Sours & Location \\
\hline A & Penjwen product fresh & Sawdust compost & $\begin{array}{l}\text { Penjwen, Halabja, Kurdistan Region- } \\
\text { Iraq }\end{array}$ \\
\hline B & Sulaimani Product fresh & Sawdust compost & $\begin{array}{l}\text { Setak, Sulaimani, Kurdistan Region- } \\
\text { Iraq }\end{array}$ \\
\hline $\mathrm{C}$ & $\begin{array}{l}\text { Amrican made in china caned } \\
\text { (Agaricus bisporous, water, salt } \\
\text { and ctric acid) }\end{array}$ & Caned & China \\
\hline $\mathrm{D}$ & $\begin{array}{c}\text { Valencia Netherland caned } \\
\text { (Agaricus bisporous, water, salt } \\
\text { and ctric acid) }\end{array}$ & Caned & Netherland \\
\hline $\mathrm{E}$ & Erbil Product fresh & Sawdust compost & Erbil, Kurdistan Region- Iraq \\
\hline
\end{tabular}

Muffle furnace' was used to determine ash content in samples at $600 \pm 10{ }^{0} \mathrm{C}$ for approximately 3 hours. The following equation was applied to calculate the ash content (5) [18].

Ash $\%=\frac{\text { Weight of Ash }}{\text { Wight of sample }} \times 100$

For the determination of crude fiber, 5.0 \pm 0.01 grams of mushroom free of moisture and fat were sampled, treated to the $200 \mathrm{ml}$ Sulfuric acid $0.225 \mathrm{~N}$ in a beaker, and heated for 30 minutes. After that, the samples were filtered, washed by boiling water and followed washing by $200 \mathrm{ml}$ of Sodium Hydroxide $0.313 \mathrm{~N}$. The previous processes were repeated again. The residues were ashed in muffle furnace at $600 \pm 5{ }^{\circ} \mathrm{C}$. Crude fiber was calculated by this equation (6) [18].

Crude fiber $=\frac{[100-(\text { moisture }+ \text { fat })] *(\mathrm{~W} 1-\mathrm{W} 2)}{\text { weight } \text { of } \text { sample }}$

The carbohydrate content was calculated by the following equation (7) [18].

Carbohydrate $\%=[100-$ mosture + ash + protein + fat + crude fiber $)]$

Also, metabolizable energy contents $(\mathrm{Kcal} / 100 \mathrm{~g})$ were calculated by the following equation (8) [19].

$\operatorname{ME}(\mathrm{Kal} / 100 \mathrm{~g})=(3.5 * \mathrm{CP})+(8.5 * \mathrm{CF})+(3.5 * \mathrm{NFE})$

When:

$\mathrm{CP}=(\%$ crude protein $)$

$\mathrm{CF}=(\%$ crude fat $)$

$\mathrm{NFT}=[\%$ nitrogen free extricate (carbohydrate) $]$.

Heavy metals ( $\mathrm{Fe}, \mathrm{Cu}, \mathrm{Zn}, \mathrm{Mg}, \mathrm{Mn}, \mathrm{Ni}, \mathrm{Si}, \mathrm{Na}$, and $\mathrm{Ca}$ ) were analyzed by Atomic Absorption Spectrometry, and each treatment $(2.2 \pm 0.50 \mathrm{~g}$ dried mushroom) was ashed in muffle furnace $590 \pm 20{ }^{\circ} \mathrm{C}$ for approximately 4 hours until the samples changed to white or grey. Then, the residue was dissolved in $5 \mathrm{ml}$ of HNO3 (5\%) and mixed, and after that, it was filtered [12].

The data were analyzed by ANOVA using (XLSTAT-pro version 7.5.2 window) program, fisher (LSD) multiple comparison tests at $P<0.05$. 
Ibn Al-Haitham Jour. for Pure \& Appl. Sci. 33 (2) 2020

\section{Results and Discussions}

The metabolizable energy proportions in different marketable mushrooms have been illustrated in Figure 1. The highest metabolizable energy was obtained from treatment D $(296.105 \mathrm{kcal} \%)$ and the lowest was achieved from parameter E (223.097 kcal \%). That result showed a significant difference in various marketable mushrooms. The amount of metabolizable energy in mushrooms was affected by amount of protein, fat and carbohydrate content [20].

The results of proximate chemical compositions were given in Table 2. The values of moisture content in marketable white button mushroom (Agaricus bisporus) range from (89.387\%-95.053 \%) confirmed the highest value of moisture content to this product [20, 21$]$. Moisture content is changeable depending of temperature, post-harvest stage, time of harvesting, relative humidity of the mushroom during growth stage and storage technic [22, $23,24]$. Those results are significantly different at $(P<0.05)$. Also, percentage of dry matter values range between $4.947 \%-10.613 \%$. The results of these studies reported $9.24 \%$ [21]. and $(10.9 \%)$ [25]. Our result agrees with (8\%) [26].

The highest percentage of crud protein was taken from treatment B $(43.693 \%)$, and the lowest percentage of protein was taken from treatment E (26.07\%). According to statistical analysis, crud protein is significantly different at $(P<0.05)$. In addition, that result agrees with these researchers [21], showed (33.65\%), and [27]. displayed (31.4\%), based on dry matter have little differs from the results of the experiment.

The highest percentage of crud protein was taken from treatment B (43.693\%), and the lowest percentage of protein was taken from treatment E (26.07\%). According to statistical analysis, crud protein is significantly different at $(P<0.05)$. In addition, that result agrees with these researchers [21], showed (33.65\%), and [27]. displayed (31.4\%), based on dry matter have little differs from the results of the experiment.

The highest percentage of fat was taken from B (3.93\%), and the lowest percentage of fat content was obtained from treatment $\mathrm{C}(1.577 \%)$. Based on the statistical analysis, the percentage of fat is significantly different at $(P<0.05)$. That result agrees with [27] who reported $(2.48 \%)$.

Statically, the amount of carbohydrate in various marketable mushrooms are significantly different at $(P<0.05)$. The highest carbohydrate content was taken from treatment $\mathrm{D}(49.267 \%)$, and the lowest was taken from treatment B (15.89\%). That result agrees with (15) who achieved $(34.0 \%)$. Consequently, the amounts of crud fiber in different parameters are not an important difference. The chemical compositions in mushrooms are related to the growing technics and substrate when they are used for the growing mushrooms [1, 2, 25, 5]. Maximum crud fiber was taken from treatment $\mathrm{E}(18.48 \%)$ and the lowest was taken from treatment $\mathrm{D}(6.23 \%)$. 
Ibn Al-Haitham Jour. for Pure \& Appl. Sci. 33 (2) 2020

Table 2. Illustrated the percentage (\%) chemical composition (moisture, protein, ash, fiber, fat and carbohydrate) in different marketable mushroom.

\begin{tabular}{|c|c|c|c|c|c|c|c|}
\hline $\begin{array}{c}\text { Treatme } \\
\text { nts }\end{array}$ & $\begin{array}{c}\text { Moisture } \\
\text { \% } \\
\text { Mean } \\
\pm \text { S.E. }\end{array}$ & $\begin{array}{c}\text { Dry } \\
\text { matter\% } \\
\text { Mean } \\
\pm \text { S.E. }\end{array}$ & $\begin{array}{l}\text { Ash\% } \\
\text { Mean } \\
\pm \text { S.E. }\end{array}$ & $\begin{array}{l}\text { Fat } \% \\
\text { Mean } \\
\pm \text { S.E. }\end{array}$ & $\begin{array}{l}\text { Protein \% } \\
\text { Mean } \\
\pm \text { S.E. }\end{array}$ & $\begin{array}{c}\text { Carbohydrat } \\
\text { e \% } \\
\text { Mean } \pm \text { S.E. }\end{array}$ & $\begin{array}{c}\text { Crude } \\
\text { Fiber\% } \\
\text { Mean } \pm \text { S.E. }\end{array}$ \\
\hline A & $\begin{array}{c}90.200 \pm 1 . \\
79^{\mathrm{a}}\end{array}$ & $\begin{array}{c}10.010 \pm 1.1 \\
1^{\mathrm{a}}\end{array}$ & $\begin{array}{c}12.975 \pm 0 . \\
22^{\mathrm{a}}\end{array}$ & $\begin{array}{c}3.777 \pm 0.8 \\
2^{\mathrm{a}}\end{array}$ & $\begin{array}{c}31.563 \pm 0 . \\
05^{\mathrm{a}}\end{array}$ & $29.150 \pm 1.44^{\mathrm{a}}$ & $\begin{array}{c}12.525 \pm 1.79 \\
\text { a }\end{array}$ \\
\hline $\mathrm{B}$ & $\begin{array}{c}89.387 \pm 0 . \\
69^{\mathrm{ab}}\end{array}$ & $\begin{array}{c}10.613 \pm 0.5 \\
9^{\mathrm{ab}}\end{array}$ & $\begin{array}{c}10.073 \pm 0 . \\
25^{\mathrm{b}}\end{array}$ & $\begin{array}{c}3.930 \pm 0.1 \\
9^{\mathrm{a}}\end{array}$ & $\begin{array}{c}43.693 \pm 0 . \\
11^{\mathrm{b}}\end{array}$ & $15.890 \pm 0.03^{b}$ & $\begin{array}{c}15.800 \pm 0.12 \\
\text { a }\end{array}$ \\
\hline $\mathrm{C}$ & $\begin{array}{c}91.423 \pm 0 . \\
82^{\text {ac }}\end{array}$ & $\begin{array}{c}8.577 \pm 0.70 \\
\text { ac }\end{array}$ & $\begin{array}{c}11.385 \pm 0 . \\
40^{\mathrm{ab}}\end{array}$ & $\begin{array}{c}1.577 \pm 0.5 \\
2^{\mathrm{b}}\end{array}$ & $\begin{array}{c}30.160 \pm 0 . \\
01^{\mathrm{c}}\end{array}$ & $33.060 \pm 1.27^{\mathrm{a}}$ & $\begin{array}{c}15.242 \pm 1.30 \\
\text { a }\end{array}$ \\
\hline $\mathrm{D}$ & $\begin{array}{c}95.053 \pm 0 . \\
12^{\mathrm{d}}\end{array}$ & $\begin{array}{c}4.947 \pm 0.10 \\
\mathrm{~d}\end{array}$ & $\begin{array}{c}8.160 \pm 0.2 \\
8^{c}\end{array}$ & $\begin{array}{c}2.757 \pm 1.9 \\
9^{\mathrm{ab}}\end{array}$ & $\begin{array}{c}28.640 \pm 0 . \\
08^{\mathrm{d}}\end{array}$ & $49.267 \pm 0.54^{\mathrm{c}}$ & $6.230 \pm 0.18^{b}$ \\
\hline$E$ & $\begin{array}{c}92.237 \pm 0 . \\
75^{\mathrm{c}}\end{array}$ & $\begin{array}{c}7.763 \pm 0.64 \\
\mathrm{c}\end{array}$ & $\begin{array}{c}14.110 \pm 1 . \\
21^{\mathrm{a}}\end{array}$ & $\begin{array}{c}2.867 \pm 0.2 \\
0^{\mathrm{a}}\end{array}$ & $\begin{array}{c}26.070 \pm 2 . \\
22^{\mathrm{e}}\end{array}$ & $30.710 \pm 0.96^{\mathrm{a}}$ & $\begin{array}{c}18.480 \pm 0.50 \\
\text { a }\end{array}$ \\
\hline LSD & 1.294 & 1.515 & 1.668 & 1.201 & 0.867 & 6.211 & 7.339 \\
\hline
\end{tabular}

A, B, C, D and E letter: Means treatments followed by the same letter are not significantly different at $P<0.05$. S.E.: standard error

Overall, most of the studies about mineral contents in mushrooms have displayed a high amount of heavy metals. Heavy metals recorded in fruiting body of white button mushrooms in Kurdistan Region-Iraq is clarified in Table 3. The metals (Fe, Mg, Mn, $\mathrm{Cu}, \mathrm{Zn}, \mathrm{Ni}, \mathrm{Si}, \mathrm{Na}$, and $\mathrm{Ca}$ ) in mushrooms were based on dry weight. Mushroom in comparison with vegetable provides a good recourse of minerals, so fresh mushrooms is better than caned mushrooms according to $[21,27]$.

Iron is a main element of almost all living organisms, especially human body, and it participates in most metabolic processes [26]. The highest Iron ( $\mathrm{Fe}$ ) content in marketable mushrooms was achieved from treatment $\mathrm{C}(15 \mathrm{ppm})$. This result displays a significant difference compared to other treatments, and the lowest Iron content was given from $\mathrm{E}(6 \mathrm{ppm})$. However, the amounts of Zinc (Zn) content in mushroom samples range between 5-15 ppm that was given from treatment (A and D - B). In addition, Zinc has an important role in various enzymes [28]. The World Health Organization (WHO) recommends 60-80 ppm intake/ daily [29].

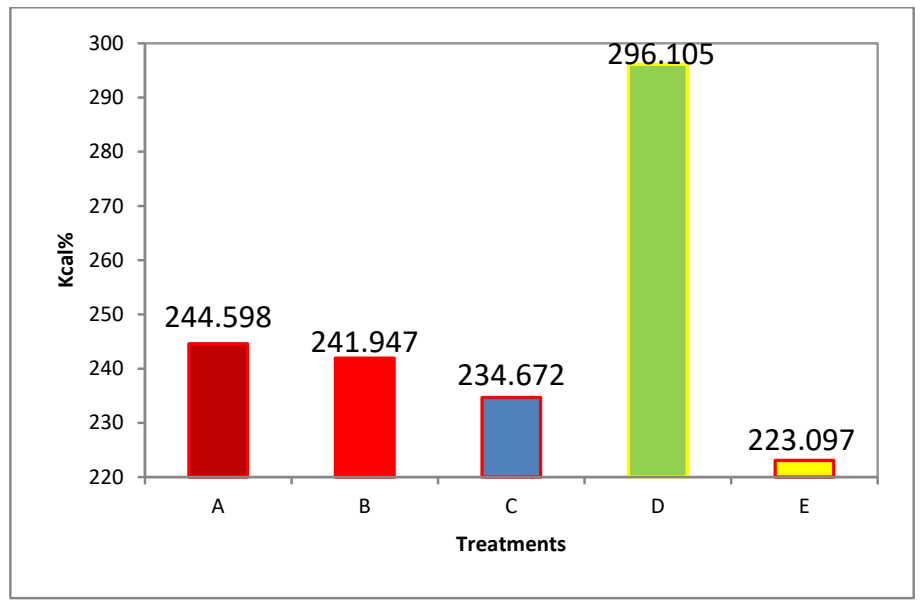

Figure 1. Metabolizable energy content $(\mathrm{Kcal} / 100 \mathrm{~g})$ in different treatments. 
Despite Manganese has an extremely important role in mitochondria, it is superoxide dismutase [21]. Manganese content in the collected mushrooms ranged between $0.48-1.1 \mathrm{ppm}$. That result is limited under toxicity of the plant, and plant makes toxicity around (500-1000 ppm). Given various literature about mushroom and heavy metal contents, different metal contents have been reported 10-73 ppm in different parts of mushrooms [21]. $8.3 \mathrm{ppm}$ [23]. $0.42-5.5 \mathrm{ppm}$ [20]. And $4.16 \mathrm{ppm}$ [30]. respectively. These results agree with those studies that have been carried out earlier.

The Copper content of the marketable mushrooms ranged between $0.9-3.5 \mathrm{ppm}$, and the highest Copper content was given from treatment $\mathrm{B}$, which was a significant different compared to other treatments, and the lowest Copper was given from treatment $\mathrm{D}$. That result is not risky to human bodies because the accumulation in mushrooms is nearly (100-300 ppm) [21]. Element levels are more important, in the view of the fact that levels of elements are very high in some mushrooms, and that element contents are changeable according to substrate with compost at that time of grown [30,31]. In addition, Nickle content in mushroom samples is not significant different between treatments at $P<0.05$. Maximum and minimum levels of Nickle were obtained from $(0.6-1 \mathrm{ppm})$.

The WHO recommended daily intake around (100-300 ppm) [29]. The concentration of Ni is low even though Ni is a very good nutrition for human to consume. Those results contrast with [27]. That recorded (12.57- 21.00ppm) and agree with [31]. who worked on button mushroom, rerecording (1.91 ppm).

Sodium content in marketable mushrooms is significantly different at treatment groups. Maximum level of Sodium was obtained from treatment D (1080 ppm), and its minimum level was taken from E (180 ppm). Also, Sodium levels of fresh mushroom were extremely low compared to the caned mushroom that was affected by the packaging process. Most of the researchers stated that mushroom contained the lower of sodium [27, 29, 30, 32]. So, our results agree with those researchers worked on mushroom that recorded (350-1000 ppm) [33]. Also, Sodium, Calcium, and Magnesium were the most common mineral in mushrooms [33].

Table 3. Illustrated mineral content in marketable mushroom (Agaricus bisporus).

\begin{tabular}{|c|c|c|c|c|c|c|c|c|c|}
\hline $\begin{array}{c}\text { Treatment } \\
\mathbf{s}\end{array}$ & $\begin{array}{c}\mathbf{F e} \\
/ \mathbf{p p m}\end{array}$ & $\begin{array}{c}\mathbf{Z n} \\
/ \mathbf{p p m}\end{array}$ & $\begin{array}{c}\mathbf{M n} \\
/ \mathbf{p p m}\end{array}$ & $\begin{array}{c}\mathbf{C u} \\
/ \mathbf{p p m}\end{array}$ & $\begin{array}{c}\mathbf{N i} \\
/ \mathbf{p p m}\end{array}$ & $\begin{array}{c}\mathbf{N a} \\
/ \mathbf{p p m}\end{array}$ & $\begin{array}{c}\mathbf{C a} / \mathbf{p p} \\
\mathbf{m}\end{array}$ & $\begin{array}{c}\mathbf{M g} / \mathbf{p p} \\
\mathbf{m}\end{array}$ & $\begin{array}{c}\mathbf{S i} / \mathbf{p p} \\
\mathbf{m}\end{array}$ \\
\hline $\mathrm{A}$ & $6.8^{\mathrm{a}}$ & $5^{\mathrm{a}}$ & $0.52^{\mathrm{a}}$ & $2^{\mathrm{a}}$ & $1^{\mathrm{a}}$ & $185^{\mathrm{a}}$ & $6.5^{\mathrm{ab}}$ & $80^{\mathrm{ab}}$ & $350^{\mathrm{a}}$ \\
\hline $\mathrm{B}$ & $8^{\mathrm{a}}$ & $15^{\mathrm{b}}$ & $1.1^{\mathrm{b}}$ & $3.5^{\mathrm{b}}$ & $1^{\mathrm{a}}$ & $230^{\mathrm{b}}$ & $6.7^{\mathrm{ab}}$ & $90^{\mathrm{ab}}$ & $120^{\mathrm{b}}$ \\
\hline $\mathrm{C}$ & $15^{\mathrm{b}}$ & $8^{\mathrm{a}}$ & $0.64^{\mathrm{a}}$ & $1.7^{\mathrm{a}}$ & $0.8^{\mathrm{a}}$ & $1050^{\mathrm{c}}$ & $8^{\mathrm{a}}$ & $48^{\mathrm{c}}$ & $140^{\mathrm{b}}$ \\
\hline $\mathrm{D}$ & $7^{\mathrm{a}}$ & $5^{\mathrm{a}}$ & $0.5^{\mathrm{a}}$ & $0.9^{\mathrm{a}}$ & $0.8^{\mathrm{a}}$ & $1080^{\mathrm{d}}$ & $5^{\mathrm{bc}}$ & $35^{\mathrm{c}}$ & $200^{\mathrm{c}}$ \\
\hline $\mathrm{E}$ & $6^{\mathrm{a}}$ & $5.2^{\mathrm{a}}$ & $0.48^{\mathrm{a}}$ & $2.2^{\mathrm{a}}$ & $0.6^{\mathrm{a}}$ & $180^{\mathrm{a}}$ & $3.5^{\mathrm{c}}$ & $65^{\mathrm{a}}$ & $210^{\mathrm{c}}$ \\
\hline $\mathrm{LSD}$ & 3.452 & 3.586 & 0.208 & 0.640 & 0.372 & 16.693 & 2.257 & 15.943 & 24.744 \\
\hline
\end{tabular}

The a,b,c and d letter: Means treatments followed by the same letter were not significantly different at $P<0.05$. Calcium levels in marketable mushrooms showed significant differences between treatments at $P<0.05$. The highest $\mathrm{Ca}$ level was given from treatment $\mathrm{C}(8 \mathrm{ppm})$, and its lowest $\mathrm{Ca}$ was obtained from treatment $\mathrm{E}(3.5 \mathrm{ppm})$. The most element level in different researchers ranged between $(1.30-23.0 \mathrm{ppm})$, mentioned by [33]. Those results showed by different researchers agree with (10.30 ppm) [27]. And (1.4 ppm) [34]. And disagree with (25.0 ppm) [21]. In addition, Calcium has an important role to human body, and it is an essential compound of the human bone [27]. 
Ibn Al-Haitham Jour. for Pure \& Appl. Sci. 33 (2) 2020

According to the results obtained from this study, the highest Magnesium content was obtained from treatment B (90.0 ppm), and the lowest $\mathrm{Mg}$ was given from treatment D (35.0 $\mathrm{ppm})$. Those results obtained from the analysis of marketable mushrooms show significant differences between treatments at $P<0.0 .5$. As a matter of fact, the results agree with [27]. Who recorded (130 ppm) and disagree with [34].

Silicon is a naturally mineral different kind of foods that naturally contains silicon such as coffee, water, some vegetables. Silicon has another medicine supply, which people take for weak bones [27]. Silicon content level in the samples ranged between 350-120 ppm in treatment A and B. Those displayed significant differences between treatments. However, those results contrast with [27]. Who obtained $(811.67 \mathrm{ppm})$. Consequently, mushroom is suitable to consume for people without making toxicity in human body.

\section{Conclusion}

Cultivated mushroom is a good resource of human nutrition and is proved to have different kinds of minerals. In addition, Sulaimani cultivation of mushroom grown on sawdust is the best nutritional resource to the human at that region and most of the results are below the limitation safety level of daily intake for human by FAO/WHO. Thus, this study recommends that people should consume fresh mushroom instead of caned mushroom. Also, our study recommends more studies on marketable food and mushroom with different elements and chemical composition. Even, it recommends more studies that will apply on effects of various elements in mushroom on human.

\section{References}

1. Kong, W.S. Descriptions of commercially important Pleurotus species. Oyster mushroom cultivation. Part II. Oyster mushrooms. Seoul: Heineart Incorporation.2004, 54-61.

2. Stamets, P. Growing gourmet and medicinal mushrooms. Ten Speed pres.1993, ISBN: 0-89815-608-4.

3. Mueller, G.M.; Schmit, J.P.; Leacock, P.R.; Buyck, B.; Cifuentes, J.; Desjardin, D.E.; Halling, R.E.; Hjortstam, K.; Iturriaga, T.; Larsson, K.H.; Lodge, D.J. Global diversity and distribution of macrofungi. Biodiver Conserv.2007, 16, 1, 37-48.

4. Shu-Ting, C.; Miles, P.G. Mushrooms: Cultivation, Nutritional Value, Medicinal Effect, and Environmental Impact. $2^{\text {nd }}$ Ed , CRC Pressp.2004, 159-185.

5. Thongnaitham, M. Organic Mushroom Cultivation Manual, Freeland Foundation.2012, 591, 56.

6. Royse, D.J. Cultivation of Oyster Mushroom. The Pennsylvania State University, USA, 2003.

7. Royse, D.J.; Baars, J.; Tan, Q. Current overview of mushroom production in the world. Edible and Medicinal Mushrooms. Technol Appl.2016, 5-13.

8. United States Department of Agriculture Economic Research Service. Yearbook Tables. Retrieved from https://www. ers.usda.gov/data-products/vegetables-and-pulses, data/ year booktables / \#Supply and Utilization: Fresh Market, 2017.

9. Manzi, P.; Aguzzi, A.; Pizzoferrato, L. Nutritional value of mushrooms widely consumed in Italy. Food Chem.2001, 73, 3, 321-325.

10. Dhamodharan, G.; Mirunalini, S. A novel Medicinal Characterization of Agaricus bisporus (white button mushroom). Pharmacol Online.2010, 2, 456-463. 
11. Muszyńska, B.; Piotrowska, J.; Krakowska, A.; Gruba, A.; Kała, K.; Sułkowska-Ziaja, K.; Kryczyk, A.; Opoka, W. Study of physiologically active components in different parts of fruiting bodies of varieties of Agaricus bisporus (white mushroom). Europ Food Res Technol.2017, 243, 12, 2135-2145.

12. Khan, M.A.; Tania, M.; Amin, S.R.; Alam, N.; Uddin, M.N. An Investigation on the nutritional composition of mushroom (Pleurotus florida) Cultivated on Different Substrates. Bangl J Mushroom.2008, 2, 2, 17-23.

13. García, M.Á.; Alonso, J.; Melgar, M.J. Lead in edible mushrooms: levels and bioaccumulation factors. Journal of Hazardous Materials.2009, 167, 1-3, 777-783.

14. Nadir, H. A.; Ali, A. J.; Muhammed, G.; Muhammed, A.R. Deterrmination of yield and quality of oystre mushroom (Pleurotus florida) using different substrates in Hlabja, Kurdistan Regin-Iraq. Plant Prod Mansoura Univ.2016, 7, 7, 787-790.

15. AOAC. Official methods of analysis. Association of Official Analytical Chemists. Washington D.C, 2000.

16. Folch, J.; Lees, M.; Sloane Stanley, G.H. A simple method for the isolation and purification of total lipides from animal tissues. J Biol Chem.1957, 226, 1, 497-509.

17. Burtis, C.A.; Ashwood, E.R.; Bruns, D.E. Tietz textbook of clinical chemistry and molecular diagnostics-e-book. Elsevier Health Sciences, 2012.

18. Raghuramulu, N.; Madhavan, N.K.; Kalyanasundaram, S. A. A Manual of Laboratory Techniques. National Institute of Nutrition Indian Council of Medical Research, 2003, $56-58$.

19. Kortei, N.K.; Odamtten, G.T.; Obodai, M.; Wiafe-Kwagyan, M. Nutritional qualities and shelf life extension of gamma irradiated dried Pleurotus ostreatus (Jacq. Ex. Fr.) Kummer preserved in two different storage packs. Food Sci Technol.2017, 5, 1, 9-16.

20. Mihalcea, L.I.; Bucur, F.C.; Cantaragiu, A.M.M.; Gurgu, L.C.; Borda, D.D.; Iordachescu, G.S. Temperature influence on the Agaricus bisporus mushrooms dehydration process. Sci Study Res Chemist Chem Eng Biotechnol, Food Indus.2016, 323-333.

21. Nasiri, F.; Tarzi, B.G.; Bassiri, A.; Hoseini, S.E. Comparative study on some chemical compounds of button mushrooms (Agaricus bisporus) cap and stipe during the first to third flushes. Ann Biol Res.2012, 3, 12, 5677-5680.

22. Donker, H.C.W.; Van As, H.; Edzes, H.T.; Jans, A.W.H. NMR imaging of white button mushroom (Agaricus bisporis) at various magnetic fields. Magn Reson Imag.1996, 14, $10,1205-1215$.

23. Kumar, B.; Kumari, C.; Kumar, M. Comparative Study of the Nutritional Content of White Button Mushroom [Agaricus bisporus (Lange) Imbach] after Application of Pseudomonas putida. Int J Curr Microbiol Appl Sci.2018, 7, 2, 2210-2215.

24. Taghizadeh, M.; Gowen, A.; O’Donnell, C.P. Prediction of white button mushroom (Agaricus bisporus) moisture content using hyperspectral imaging. Sens Instrumen Food Quality Safety.2009, 3, 4, 219.

25. Ishara, J.R.; Sila, D.N.; Kenji, G.M.; Buzera, A.K.; Mushagalusa, G.N. Nutritional and Physical Attributes of Maize-mushroom Complementary Porridges as Influenced by Mushroom Species and Ratio. Am J Food Nut.2018, 6, 1, 17-27. 
Ibn Al-Haitham Jour. for Pure \& Appl. Sci. 33 (2) 2020

26. Mshandete, A.M.; Cuff, J. Proximate and nutrient composition of three types of indigenous edible wild mushrooms grown in Tanzania and their utilization prospects. Afr J Food Agric Nutr Develop.2007, 7, 6.

27. Poongkodi, G.K.; Harithra Priya, G.P.; Harshitha Priya, G.P. Nutrient contents of edible mushrooms, Agaricus bisporus and Pleurotus ostreatus. Int J Mod Chem Appl Sci.2015, 2, 2, 78-86.

28. Mattila, P.; Könkö, K.; Eurola, M.; Pihlava, J.M.; Astola, J.; Vahteristo, L.; Hietaniemi, V.; Kumpulainen, J.; Valtonen, M.; Piironen, V. Contents of vitamins, mineral elements, and some phenolic compounds in cultivated mushrooms. J Agric Food Chem.2001, 49, 5, 2343-2348.

29. Joint, F.A.O. WHO Expert Consultation on Human Vitamin and Mineral Requirements and World Health Organization Dept of Nutrition for Health and Development Vitamin and mineral requirements in human nutrition. Vitamin and mineral requirements in human nutrition. 2nd ed., Geneva: World Health Organization.2005, 341.

30. Vetter, J. Mineral elements in the important cultivated mushrooms Agaricus bisporus and Pleurotus ostreatus. Food Chem.1994, 50, 3, 277-279.

31. Owaid, M.N. Mineral elements content in two sources of Agaricus bisporus in Iraqi market. J Adv Appl Sci.2015, 3, 2, 46-50.

32. Tüzen, M.; Özdemir, M.; Demirbaş, A. Heavy metal bioaccumulation by cultivated Agaricus bisporus from artificially enriched substrates. Zeitschrift für Lebensmitteluntersuchung und-Forschung A.1998, 206, 6, 417-419.

33. Directorate, E. Joint meeting of the chemicals committee and the working party on chemicals, pesticides and biotechnology, OECD Environment, Health and Safety Publications Series on the Safety of Novel Foods and Feeds No.2007, 15.

34. Györfi, J.; Geösel, A.; Vetter, J. Mineral composition of different strains of edible medicinal mushroom Agaricus subrufescens Peck. J Med Food.2010, 13, 6, 1510-1514. 